\title{
Colwellia piezophila sp. nov., a novel piezophilic species from deep-sea sediments of the Japan Trench
}

Correspondence

Yuichi Nogi

nogiy@jamstec.go.jp

\author{
Yuichi Nogi, ${ }^{1}$ Shoichi Hosoya, ${ }^{1}$ Chiaki Kato ${ }^{2}$ and Koki Horikoshi ${ }^{1}$
}

The DEEPSTAR Group ${ }^{1}$ and Marine Ecosystems Research Department ${ }^{2}$, Japan Marine Science and Technology Center (JAMSTEC), 2-15 Natsushima-cho, Yokosuka 237-0061, Japan

\begin{abstract}
Two strains of obligately piezophilic bacteria were isolated from sediment collected from the bottom surface of a small canyon on the seaward slope of the Japan Trench at a depth of $6278 \mathrm{~m}$. The isolated strains, $Y 223 G^{\top}$ and $Y 251 E$, are closely affiliated with members of the genus Colwellia on the basis of $16 \mathrm{~S}$ rRNA gene sequence analysis. The $\mathrm{G}+\mathrm{C}$ contents of both strains were about 39 mol\%. DNA-DNA hybridization values between these strains and Colwellia reference strains were significantly lower than those accepted as the phylogenetic definition of a species. The novel strains are Gram-negative, polarly flagellated and facultatively anaerobic. The optimal pressure for growth was $60 \mathrm{MPa}$ at both 4 and $10^{\circ} \mathrm{C}$; the most rapid growth rate was observed at $10^{\circ} \mathrm{C}$ and $60 \mathrm{MPa}$. No growth occurred at $15^{\circ} \mathrm{C}$ under any pressure studied. The major isoprenoid quinone is $Q-8$. The predominant cellular fatty acids are $C 16: 0$ and $C 16: 1$. Based on the taxonomic differences observed, the isolated strains appear to represent a novel obligately piezophilic Colwellia species. The name Colwellia piezophila sp. nov. (type strain Y223G ${ }^{\top}=\mathrm{JCM}$ $11831^{\top}=$ ATCC BAA- $637^{\top}$ ) is proposed.
\end{abstract}

Numerous deep-sea piezophilic bacterial strains have been isolated and characterized in an effort to understand the interaction between the deep-sea environment and its microbial inhabitants (Bartlett, 1999; Deming \& Baross, 1993; Kato et al., 1995; Yayanos et al., 1979). Piezophilic bacteria, as defined by Yayanos (2001), are bacteria that have their maximum growth rate at high pressure over all permissible temperatures. All psychropiezophilic bacteria isolated to date are members of the $\gamma$-Proteobacteria, according to phylogenetic classifications based on $16 \mathrm{~S}$ rRNA gene sequence information. Nogi et al. (2002) reported that cultivated psychropiezophilic deep-sea bacteria were affiliated with one of five genera within the $\gamma$-Proteobacteria: Shewanella, Photobacterium, Colwellia, Moritella and Psychromonas.

In this paper, results of taxonomic studies on obligately piezophilic strains isolated from the deepest cold-seep environment in the Japan Trench are presented. Several lines

Published online ahead of print on 12 March 2004 as DOI 10.1099/ ijs.0.03049-0.

Abbreviations: DHA, docosahexaenoic acid; EPA, eicosapentaenoic acid; PUFAs, polyunsaturated fatty acids.

The GenBank/EMBL/DDBJ accession number for the 16S rRNA gene sequence of strain $Y_{223 G^{\top}}$ is $A B 094412$.

A $16 \mathrm{~S}$ rRNA gene-based phylogenetic tree showing the relationship between Colwellia piezophila and piezophilic bacteria within the $\gamma$ Proteobacteria is available as supplementary material in IJSEM Online. of evidence indicate that two of these isolates, strains Y223G $\mathrm{G}^{\mathrm{T}}$ and Y251E, represent a novel species within the genus Colwellia. In the genus Colwellia, the only deep-sea piezophilic species reported is Colwellia hadaliensis strain BNL-1 ${ }^{\mathrm{T}}$ (Deming et al., 1988), although no public culture collection maintains C. hadaliensis. Species of the genus Colwellia are defined as facultative anaerobes and psychrophilic bacteria (Deming et al., 1988). Bowman et al. (1998) reported that Colwellia species produce docosahexaenoic acid (DHA; C22:603). Psychropiezophilic Shewanella and Photobacterium strains produce eicosapentaenoic acid (EPA; C20:5 $\omega 3$ ), Moritella strains produce DHA (Nogi \& Kato, 1999; Kato \& Nogi, 2001; Nogi et al., 1998a) and Psychromonas kaikoae produces both EPA and DHA (Nogi et al., 2002). Generally, psychropiezophilic bacteria produce either one or both of these long-chain polyunsaturated fatty acids (PUFAs). However, unlike other psychropiezophilic bacteria, our isolates did not produce either EPA or DHA in the membrane layer. Based on the taxonomic differences observed, the isolated strains appear to represent a novel obligately piezophilic Colwellia species, for which the name Colwellia piezophila sp. nov. is proposed.

Deep-sea sediment samples were collected by means of sterilized mud samplers (Ikemoto \& Kyo, 1993) on the submersible Shinkai 6500 from the bottom of a small deep-sea canyon on the Japan Trench $\left(40^{\circ} 2 \cdot 8^{\prime} \mathrm{N} 144^{\circ} 16 \cdot 6^{\prime}\right.$ E) at a depth of $6278 \mathrm{~m}$ during cruise YK 01-06, dive \#6K621. The mud samples were taken by the submersible's 
manipulator and put into the sample holder of the sterilized sampler. The samples were then carried to the sea surface without changing temperature, but with a change in pressure. A part of each sample was cultivated in marine broth 2216 (Difco Laboratories) at $4{ }^{\circ} \mathrm{C}$ and $60 \mathrm{MPa}$ in a pressure vessel for about 2 weeks. Strains $\mathrm{Y} 223 \mathrm{G}^{\mathrm{T}}$ and Y251E were isolated using the low-melting agar method (Kato et al., 1995). Colwellia maris JCM $10085^{\mathrm{T}}$ (Yumoto et al., 1998) and Colwellia psychrerythraea ATCC $27364^{\mathrm{T}}$ (Deming et al., 1988) were used as reference strains. These bacteria were maintained in marine broth 2216. C. maris was grown at $15^{\circ} \mathrm{C}$ and atmospheric pressure, C. psychrerythraea was grown at $10^{\circ} \mathrm{C}$ and atmospheric pressure and the isolated piezophilic strains were grown at $10^{\circ} \mathrm{C}$ and $60 \mathrm{MPa}$. Highpressure cultivation utilized a liquid hydraulic system. Piezophilic bacteria were cultivated in plastic bags containing liquid medium in a pressure vessel (made of stainless steel SUS304). To supply oxygen to the cultures for the optimal growth pressure and temperature tests and the $\mathrm{O} / \mathrm{F}$ test, fluorinert (FC-72; Sumitomo-3M) saturated with gas was added ( $20 \%$ total volume). This culture method followed a previously reported procedure (Kato et al., 1994; Yanagibayashi et al., 1999).

Optimal growth pressure and temperature were determined by optical density. Cells were counted and cell form was confirmed microscopically in marine broth 2216 under aerobic conditions at each pressure and temperature tested.

Physiological tests were performed using a slight modification of the general procedures described by Barrow \& Feltham (1993) and DeLong et al. (1997). All high-pressure physiological tests were performed in tandem with uninoculated blank controls according to the following procedure. Acid production from sugars was assessed using modified O/F medium (Hugh \& Leifson, 1953) containing $0.5 \times$ artificial sea water $(1.5 \% \mathrm{NaCl}, 0.035 \% \mathrm{KCl}, 0.54 \%$ $\left.\mathrm{MgCl}_{2} \cdot 6 \mathrm{H}_{2} \mathrm{O}, 0 \cdot 27 \% \mathrm{MgSO}_{4} .7 \mathrm{H}_{2} \mathrm{O}, 0 \cdot 05 \% \mathrm{CaCl}_{2} .2 \mathrm{H}_{2} \mathrm{O}\right)$, $0.05 \% \mathrm{NH}_{4} \mathrm{H}_{2} \mathrm{PO}_{4}, 0.005 \%$ yeast extract, $0 \cdot 1 \% \mathrm{Na}_{2} \mathrm{CO}_{3}$, $1 \%$ sugar and $0.003 \%$ bromothymol blue. The $\mathrm{pH}$ of the medium was adjusted to $7 \cdot 1$ at $20^{\circ} \mathrm{C}$. After capping, the tube was sealed with Parafilm and incubated at $60 \mathrm{MPa}$ and $10^{\circ} \mathrm{C}$ for several days (Nogi et al., 2002). Physiological tests under high-pressure conditions to examine hydrogen sulfide production from thiosulfate and the production of indole, oxidase and catalase were performed according to previously described methods (Nogi \& Kato, 1999). Gelatinase, protease and amylase activities were detected in ultrasonically treated cultured cells.

Cells of strain $\mathrm{Y}_{223 \mathrm{G}^{\mathrm{T}}}$ were Gram-negative rods, 2.0$3.0 \mu \mathrm{m}$ long and $0 \cdot 8-1 \cdot 0 \mu \mathrm{m}$ wide, motile by means of a single unsheathed polar flagellum. This strain was unable to grow at atmospheric pressure at $2-15^{\circ} \mathrm{C}$, although it grew well in pressure vessels under hydrostatic pressures of $10-80 \mathrm{MPa}$ at $4{ }^{\circ} \mathrm{C}$ and $40-80 \mathrm{MPa}$ at $10^{\circ} \mathrm{C}$. No growth occurred at $15^{\circ} \mathrm{C}$ under any pressure examined. The most rapid growth rate (about $0 \cdot 14 \mathrm{~h}^{-1}$ ) was observed at $60 \mathrm{MPa}$ and $10^{\circ} \mathrm{C}$ (Fig. 1a), which compares well to rates observed for the closely related obligate piezophile $C$. hadaliensis $\left(0 \cdot 12 \mathrm{~h}^{-1}\right.$ at $90 \mathrm{MPa}$ and $10^{\circ} \mathrm{C}$; Deming et al., 1988). The C. psychrerythraea reference strain was not able to grow under such high-pressure conditions (Fig. 1b) and the growth rate of $C$. maris showed greater pressure sensitivity.

Characteristics of the isolated piezophilic Colwellia strains and the reference strains are shown in Table 1. Strains $\mathrm{Y}_{223 \mathrm{G}^{\mathrm{T}}}$ and Y251E are facultatively anaerobic chemoorganotrophs, displaying both respiratory and fermentative types of metabolism. Other characteristics of $\mathrm{Y}_{2} 23 \mathrm{G}^{\mathrm{T}}$ and Y251E are as follows. Acid, but not gas, is produced from D-glucose, maltose and xylose. Catalase and cytochrome oxidase test results are positive and gelatin is hydrolysed. Nitrate is reduced to nitrite, but nitrite is not reduced. Test results for protease, chitinase, amylase, $\mathrm{H}_{2} \mathrm{~S}$ and indole production are negative. The following compounds are not utilized: L-arabinose, cellobiose, D-fructose, D-galactose, glycerol, myo-inositol, D-lactose, D-mannitol, D-mannose, D-raffinose, L-rhamnose, D-sorbitol, sucrose and D-trehalose.
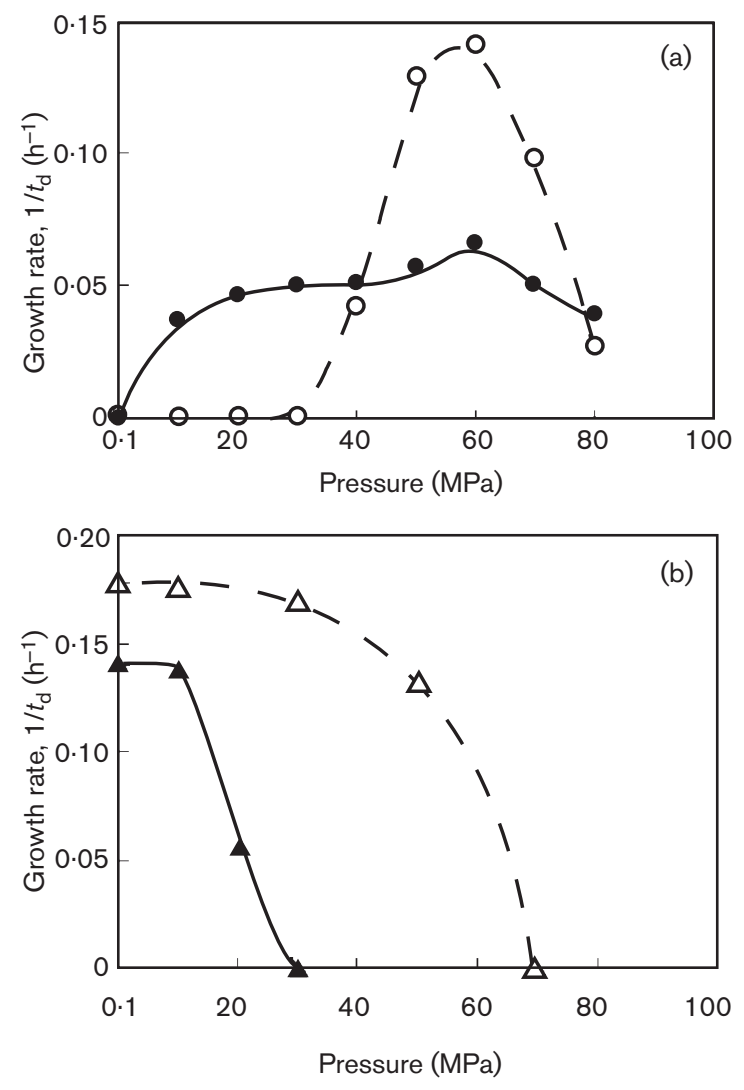

Fig. 1. (a) Pressure-dependent growth rate of Colwellia piezophila strain $\mathrm{Y}_{223 G^{\top}}$ at $4{ }^{\circ} \mathrm{C}(0)$ and $10^{\circ} \mathrm{C}(\bigcirc)$. (b) Pressuredependent growth rate of C. psychrerythraea at $10^{\circ} \mathrm{C}$ (optimal temperature) (A) and of $\mathrm{C}$. maris at $15^{\circ} \mathrm{C}$ (optimal temperature) $(\triangle)$. Growth rates were determined by optical density; $t_{\mathrm{d}}$, doubling time $(h)$. 
Table 1. Phenotypic characteristics of isolates $Y 223 G^{\top}$ and Y251E, and related Colwellia strains

Species: 1, C. piezophila (Y223G $\mathrm{G}^{\mathrm{T}}$ and $\left.\mathrm{Y} 251 \mathrm{E}\right) ; 2$, C. maris; 3. C. psychrerythraea. Data are from this study and Bowman et al. (1998). All species are Gram-negative rods that do not form spores and are motile by means of a polar flagellum. All strains are positive for catalase and oxidase reactions, hydrolysis of gelatin and nitrate reduction to nitrite. The major isoprenoid quinone type is Q-8. Acid is produced from D-glucose. All strains are negative for production of $\mathrm{H}_{2} \mathrm{~S}$, indole, gas from carbohydrates and acid production from L-arabinose, D-fructose, D-galactose, glycerol, myo-inositol, D-lactose, D-mannitol, D-mannose, D-raffinose, L-rhamnose, D-sorbitol, sucrose and D-trehalose. +, Positive; -, negative; ND, no data available.

\begin{tabular}{|lccc|}
\hline Character & $\mathbf{1}$ & $\mathbf{2}$ & $\mathbf{3}$ \\
\hline Optimum growth: & & & \\
Temperature $\left({ }^{\circ} \mathrm{C}\right)$ & 10 & 15 & 10 \\
Pressure (MPa) & 60 & $0 \cdot 1$ & $0 \cdot 1$ \\
DNA G+C content (mol\%) & $38 \cdot 5-39 \cdot 1$ & $36 \cdot 9$ & 40 \\
Hydrolysis of: & & & \\
Casein & - & - & + \\
Chitin & - & - & + \\
Starch & - & + & + \\
Nitrite reduction to nitrogen & - & + & ND \\
Acid production from: & & & \\
Cellobiose & - & + & - \\
Maltose & + & - & + \\
Xylose & + & - & - \\
\end{tabular}

The $\mathrm{G}+\mathrm{C}$ content of the DNA is $38 \cdot 5-39 \cdot 1 \mathrm{~mol} \%$. The major isoprenoid quinone is Q-8 (ubiquinone-8). The C. maris reference strain shares some physiological characteristics with the isolated strains, including the profile of carbohydrates utilized. However, unlike C. maris, the two Japan Trench strains do not hydrolyse starch, reduce nitrite or produce acid from cellobiose, and are unable to grow at atmospheric pressure. Although very few taxonomic characteristics of piezophilic C. hadaliensis are described in the literature (Deming et al., 1988), the main characteristics in which it differs from the newly isolated strains are its ability to hydrolyse chitin and its DNA G + C content of $45 \cdot 7 \mathrm{~mol} \%$.

To determine phylogenetic relationships, 16S rRNA gene sequences of strains $\mathrm{Y}_{22} 2 \mathrm{G}^{\mathrm{T}}$ and $\mathrm{Y} 251 \mathrm{E}$ were determined by direct sequencing of PCR-amplified DNA according to a previously described method (Kato et al., 1998). Nucleotide substitution rates ( $K_{\text {nuc }}$; Kimura, 1980) were determined and a distance matrix tree was constructed using the neighbour-joining method (Saitou \& Nei, 1987) with the program CLUSTAL_W (Thompson et al., 1994). Alignment gaps and unidentified base positions were not taken into consideration in the calculations. The topology of the phylogenetic tree was evaluated by performing bootstrap analysis with 1000 bootstrapped trials. The results of phylogenetic analyses based on 16S rRNA gene sequence information are shown in Fig. 2 (see also the phylogenetic tree available as supplementary material in IJSEM Online). Strains Y223G ${ }^{\mathrm{T}}$ and Y251E fall into the genus Colwellia and are closely related to the psychrophilic strain C. maris. For analysis of relatedness, DNA-DNA hybridization was carried out at $40{ }^{\circ} \mathrm{C}$ for $4 \mathrm{~h}$ and measured fluorometrically using the method of Ezaki et al. (1989). A high level of DNADNA relatedness (98-100\%) was found between strains $\mathrm{Y}_{223 \mathrm{G}^{\mathrm{T}}}$ and Y251E. The relatedness between $\mathrm{Y} 223 \mathrm{G}^{\mathrm{T}}$ or $\mathrm{Y} 251 \mathrm{E}$ and the C. maris reference strain was less than $49 \%$, as indicated by the hybridization values obtained. This is significantly lower than that accepted as the phylogenetic definition of a species (Wayne et al., 1987). This and other results shown in Table 1 and Fig. 2 suggest that strains Y223G ${ }^{\mathrm{T}}$ and Y251E represent a novel Colwellia species.

The whole-cell fatty acid compositions of strains $\mathrm{Y}_{223 \mathrm{G}^{\mathrm{T}}}$ and Y251E and the reference strains are shown in Table 2. The major fatty acids in strains $\mathrm{Y}_{2} 23 \mathrm{G}^{\mathrm{T}}$ and $\mathrm{Y} 251 \mathrm{E}$ were C16:0 (hexadecanoic acid) and C16:1 (hexadecenoic acid). Only a low level of similarity was observed between this fatty acid profile and those of the type strains of $C$. maris and C. psychrerythraea. For example, the predominant components in the fatty acid profile of the C. maris type strain differed from those in the profile of strains $Y 223 \mathrm{G}^{\mathrm{T}}$ and Y251E, which contained substantial amounts of C14:0 (tetradecanoic acid), C17:0 (heptadecanoic acid) and C17:1 (heptadecenoic acid). The type strain of $C$. psychrerythraea had low levels of the long-chain PUFAs EPA and DHA, unlike strains $\mathrm{Y}_{223 \mathrm{G}^{\mathrm{T}}}$ and Y251E, which did not contain these fatty acids. Psychropiezophilic Shewanella and Photobacterium strains produce EPA (Nogi et al., 1998b, c), Moritella strains produce DHA (Nogi \& Kato, 1999) and P. kaikoae produces both EPA

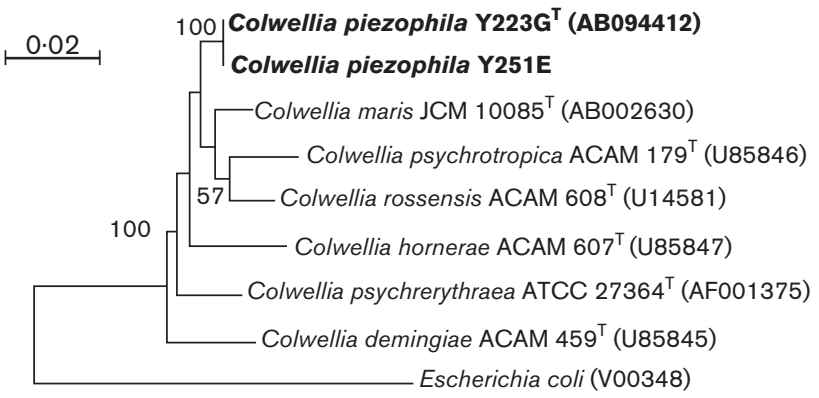

Fig. 2. Phylogenetic tree showing the relationships of strains $\mathrm{Y}^{2} 23 \mathrm{G}^{\top}$ and $\mathrm{Y} 251 \mathrm{E}$ within the genus Colwellia constructed by the neighbour-joining method and based on 16S rRNA gene sequences. Bar, 0.02 nucleotide substitutions per site. Bootstrap values were calculated from multiple resamplings of the sequence dataset, which are the basis for multiple tree topologies. A fuller phylogenetic tree showing the position of the isolates in relation to psychropiezophilic strains is available as supplementary data in IJSEM Online. 
Table 2. Whole-cell fatty acid composition (\%) of piezophilic Colwellia isolates, other Colwellia species and piezophilic species of related genera

Strains: 1, Colwellia piezophila $\mathrm{Y}_{223 \mathrm{G}^{\mathrm{T}}}$ and Y251E; 2, Colwellia maris JCM $10085^{\mathrm{T}}$ (data from this study); 3, Colwellia psychrerythraea DSM $8813^{\mathrm{T}}$ (data from Bowman et al., 1998); 4, Moritella japonica JCM $10249^{\mathrm{T}}$; 5, Photobacterium profundum JCM $10084^{\mathrm{T}}$; 6, Psychromonas kaikoae JCM $11054^{\mathrm{T}} ; 7$, Shewanella benthica ATCC $43992^{\mathrm{T}}$ (data for columns 4-7 from Nogi et al., 2002).

\begin{tabular}{|lcrcrrrr|}
\hline Fatty acid & $\mathbf{1}$ & $\mathbf{2}$ & $\mathbf{3}$ & $\mathbf{4}$ & $\mathbf{5}$ & $\mathbf{6}$ & $\mathbf{7}$ \\
\hline $12: 0$ & $1-2$ & 2 & & & 2 & 1 & 2 \\
$14: 0$ & 9 & & $5 \cdot 1-7 \cdot 8$ & 18 & 3 & 6 & 14 \\
$15: 0$ & 3 & 4 & $1 \cdot 7-11 \cdot 0$ & 1 & 1 & 1 & \\
$16: 0$ & $31-33$ & 25 & $26 \cdot 8-33 \cdot 2$ & 21 & 9 & 15 & 14 \\
$17: 0$ & & 3 & $0 \cdot 0-1 \cdot 3$ & & & & \\
$18: 0$ & & & $0 \cdot 1-2 \cdot 4$ & & 1 & & \\
iso-13:0 & & & & & 2 & & 5 \\
iso-14:0 & & & & & 4 & & \\
iso-15:0 & & & & & 2 & & 11 \\
iso-16:0 & & & & & 15 & & \\
$14: 1$ & 2 & 2 & $5 \cdot 1-7 \cdot 3$ & 2 & 3 & 10 & \\
$15: 1$ & 6 & & & & & \\
$16: 1$ & $48-50$ & 51 & $37 \cdot 6-45 \cdot 1$ & 50 & 31 & 54 & 31 \\
$17: 1$ & & 4 & $0 \cdot 0-2 \cdot 2$ & & & & \\
$18: 1$ & & & $0 \cdot 3-2 \cdot 1$ & 2 & 9 & 2 & 2 \\
$20: 5$ (EPA) & & & $0 \cdot 0-1 \cdot 5$ & & & 2 & 16 \\
$22: 6$ (DHA) & & & $5 \cdot 5-8 \cdot 0$ & 6 & 13 & 2 & \\
$3-$-OH 12:0 & $0-1$ & 3 & & & 5 & 2 & 1 \\
$3-$-OH iso-13:0 & & & & & & & 5 \\
$3-O H ~ 14: 0$ & & & & & & 4 & \\
\hline
\end{tabular}

and DHA (Nogi et al., 2002). Generally, psychropiezophilic bacteria are believed to produce EPA and/or DHA. However, Allen et al. (1999) reported that monounsaturated fatty acids, but not PUFAs, are required for growth of the piezophilic bacterium Photobacterium profundum SS9, based on analysis of pressure-sensitive mutants. In their mutation experiment, C18:1 fatty acid was necessary for growth under low-temperature and/or high-pressure conditions. However, our strains did not contain any monounsaturated fatty acids longer than C16:1. Therefore, our isolates differ from previously known psychropiezophilic bacteria in that most of the unsaturated fatty acids of these isolates have been identified as C16:1 (Table 2).

Several psychropiezophilic bacterial strains from the cold deep sea have been isolated and characterized (MacDonell \& Colwell, 1985; Nogi \& Kato, 1999; Nogi et al., 1998a, b, c, 2002); each is affiliated with one of five genera within the $\gamma$-Proteobacteria: Shewanella, Photobacterium, Colwellia, Moritella and Psychromonas (DeLong et al., 1997; Nogi et al., 2002). The first obligately piezophilic bacterium, strain MT41 isolated from the Mariana Trench, was later shown to be a member of the genus Colwellia (Yayanos et al.,
1981; DeLong et al., 1997). Since then, four obligately piezophilic bacterial strains have been isolated: $C$. hadaliensis $\mathrm{BNL}-\mathrm{1}^{\mathrm{T}}$ (Deming et al., 1988), Shewanella benthica DB21MT-2, Moritella yayanosii DB21MT- $5^{\mathrm{T}}$ (Nogi \& Kato, 1999) and P. kaikoae JCM $11054^{\mathrm{T}}$ (Nogi et al., 2002). A novel obligately piezophilic species within Colwellia, based on the results of phylogenetic analysis of $16 \mathrm{~S}$ rRNA gene sequences and several other taxonomic properties described in this paper, is therefore proposed.

On the basis of the phenotypic, genotypic and phylogenetic data, it is logical to conclude that our isolates are members of the genus Colwellia and that these deep-sea isolates represent a novel species within this genus. The name Colwellia piezophila sp. nov. is proposed, with strain $\mathrm{Y}_{2} 23 \mathrm{G}^{\mathrm{T}}(=\mathrm{JCM}$ $11831^{\mathrm{T}}=$ ATCC BAA- $637^{\mathrm{T}}$ ) as the type strain.

\section{Description of Colwellia piezophila sp. nov.}

Colwellia piezophila (piez.o.phi'la. Gr. v. piezo to press; Gr. adj. philos loving; N.L. fem. adj. piezophila loving pressure).

Cells are Gram-negative rods, $2 \cdot 0-4 \cdot 0 \times 0 \cdot 8-1 \cdot 0 \mu \mathrm{m}$, motile by means of a single unsheathed polar flagellum. Halophilic, psychrophilic and piezophilic. Optimal growth occurs at an $\mathrm{NaCl}$ concentration of about $3 \%$. No growth occurs in the absence of $\mathrm{NaCl}$. The optimal temperature and pressure for growth are $10{ }^{\circ} \mathrm{C}$ and $60 \mathrm{MPa}$, respectively. No growth occurs at atmospheric pressure and $2-15^{\circ} \mathrm{C}$ or at $15^{\circ} \mathrm{C}$ under any pressure. Facultatively anaerobic chemoorganotroph, having both respiratory and fermentative types of metabolism. Catalase and cytochrome oxidase test results are positive, gelatin is hydrolysed, nitrate is reduced to nitrite, but nitrite is not reduced. Amylase, protease, $\mathrm{H}_{2} \mathrm{~S}$ production and indole production are negative. The DNA G $+\mathrm{C}$ content of the type strain, $\mathrm{Y} 223 \mathrm{G}^{\mathrm{T}}$ ( $=\mathrm{JCM}$ $11831^{\mathrm{T}}=$ ATCC $\left.\mathrm{BAA}-637^{\mathrm{T}}\right)$, is about $39 \cdot 1 \mathrm{~mol} \%$. The major isoprenoid quinone is Q-8. The predominant cellular fatty acids are $\mathrm{C} 16: 0$ and $\mathrm{C} 16: 1$. Other characteristics are shown in Table 1.

\section{Acknowledgements}

We are very grateful to the Shinkai 6500 operation team and the crew of the MS Yokosuka for helping us to collect the deep-sea samples.

\section{References}

Allen, E. E., Facciotti, D. \& Bartlett, D. H. (1999). Monounsaturated but not polyunsaturated fatty acids are required for growth of the deep-sea bacterium Photobacterium profundum SS9 at high pressure and low temperature. Appl Environ Microbiol 65, 1710-1720.

Barrow, G. I. \& Feltham, R. K. A. (1993). Cowan and Steel's Manual for the Identification of Medical Bacteria, 3rd edn. New York: Cambridge University Press.

Bartlett, D. H. (1999). Microbial adaptations to the psychrosphere/ piezosphere. J Mol Microbiol Biotechnol 1, 93-100.

Bowman, J. P., Gosink, J. J., McCammon, S. A., Lewis, T. E., Nichols, D. S., Nichols, P. D., Skerratt, J. H., Staley, J. T. \& McMeekin, T. A. 
(1998). Colwellia demingiae sp. nov., Colwellia hornerae sp. nov., Colwellia rossensis $\mathrm{sp}$. nov. and Colwellia psychrotropica sp. nov.: psychrophilic Antarctic species with the ability to synthesize

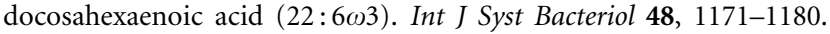

DeLong, E. F., Franks, D. G. \& Yayanos, A. A. (1997). Evolutionary relationships of cultivated psychrophilic and barophilic deep-sea bacteria. Appl Environ Microbiol 63, 2105-2108.

Deming, J. W. \& Baross, J. A. (1993). Deep-sea smokers: windows to a subsurface biosphere? Geochim Cosmochim Acta 57, 3219-3230.

Deming, J. W., Somers, L. K., Straube, W. L., Swartz, D. G. \& MacDonell, M. T. (1988). Isolation of an obligately barophilic bacterium and description of a new genus, Colwellia gen. nov. Syst Appl Microbiol 10, 152-160.

Ezaki, T., Hashimoto, Y. \& Yabuuchi, E. (1989). Fluorometric deoxyribonucleic acid-deoxyribonucleic acid hybridization in microdilution wells as an alternative to membrane filter hybridization in which radioisotopes are used to determine genetic relatedness among bacterial strains. Int J Syst Bacteriol 39, 224-229.

Hugh, R. \& Leifson, E. (1953). The taxonomic significance of fermentative versus oxidative metabolism of carbohydrates by various Gram-negative bacteria. J Bacteriol 66, 24-26.

Ikemoto, E. \& Kyo, M. (1993). Development of microbiological compact mud sampler. Jpn Mar Sci Technol Res 30, 1-16.

Kato, C. \& Nogi, Y. (2001). Correlation between phylogenetic structure and function: examples from deep-sea Shewanella. FEMS Microbiol Ecol 35, 223-230.

Kato, C., Li, L., Nogi, Y., Nakamura, Y., Tamaoka, J. \& Horikoshi, K. (1998). Extremely barophilic bacteria isolated from the Mariana Trench, Challenger Deep, at a depth of 11,000 meters. Appl Environ Microbiol 64, 1510-1513.

Kato, C., Sato, T., Smorawinska, M. \& Horikoshi, K. (1994). High pressure conditions stimulate expression of chloramphenicol acetyltransferase regulated by the lac promoter in Escherichia coli. FEMS Microbiol Lett 122, 91-96.

Kato, C., Sato, T. \& Horikoshi, K. (1995). Isolation and properties of barophilic and barotolerant bacteria from deep-sea mud samples. Biodivers Conserv 4, 1-9.

Kimura, M. (1980). A simple method for estimating evolutionary rates of base substitutions through comparative studies of nucleotide sequences. J Mol Evol 16, 111-120.

MacDonell, M. T. \& Colwell, R. R. (1985). Phylogeny of the Vibrionaceae, and recommendation for two new genera, Listonella and Shewanella. Syst Appl Microbiol 6, 171-182.
Nogi, Y. \& Kato, C. (1999). Taxonomic studies of extremely barophilic bacteria isolated from the Mariana Trench and description of Moritella yayanosii sp. nov., a new barophilic bacterial isolate. Extremophiles 3, 71-77.

Nogi, Y., Kato, C. \& Horikoshi, K. (1998a). Moritella japonica sp. nov., a novel barophilic bacterium isolated from a Japan Trench sediment. J Gen Appl Microbiol 44, 289-295.

Nogi, Y., Kato, C. \& Horikoshi, K. (1998b). Taxonomic studies of deep-sea barophilic Shewanella strains and description of Shewanella violacea sp. nov. Arch Microbiol 170, 331-338.

Nogi, Y., Masui, N. \& Kato, C. (1998c). Photobacterium profundum sp. nov., a new, moderately barophilic bacterial species isolated from a deep-sea sediment. Extremophiles 2, 1-7.

Nogi, Y., Kato, C. \& Horikoshi, K. (2002). Psychromonas kaikoae sp. nov., a novel piezophilic bacterium from the deepest cold-seep sediments in the Japan Trench. Int J Syst Evol Microbiol 52, 1527-1532.

Saitou, N. \& Nei, M. (1987). The neighbor-joining method: a new method for reconstructing phylogenetic trees. Mol Biol Evol 4, 406-425.

Thompson, J. D., Higgins, D. G. \& Gibson, T. J. (1994). CLUSTAL_W: improving the sensitivity of progressive multiple sequence alignment through sequence weighting, position-specific gap penalties and weight matrix choice. Nucleic Acids Res 22, 4673-4680.

Wayne, L. G., Brenner, D. J., Colwell, R. R. \& 9 other authors (1987). International Committee on Systematic Bacteriology. Report of the ad hoc committee on reconciliation of approaches to bacterial systematics. Int J Syst Bacteriol 37, 463-464.

Yanagibayashi, M., Nogi, Y., Li, L. \& Kato, C. (1999). Changes in the microbial community in Japan Trench sediment from a depth of $6292 \mathrm{~m}$ during cultivation without decompression. FEMS Microbiol Lett 170, 271-279.

Yayanos, A. A. (2001). Barophiles and piezophiles. In Nature Encyclopedia of Life Sciences. London: Nature Publishing. doi:10.1038/npg.els.0000341

Yayanos, A. A., Dietz, A. S. \& Van Boxtel, R. (1979). Isolation of a deep-sea barophilic bacterium and some of its growth characteristics. Science 205, 808-810.

Yayanos, A. A., Dietz, A. S. \& Van Boxtel, R. (1981). Obligately barophilic bacterium from the Mariana Trench. Proc Natl Acad Sci U S A 78, 5212-5215.

Yumoto, I., Kawasaki, K., Iwata, H., Matsuyama, H. \& Okuyama, H. (1998). Assignment of Vibrio sp. strain ABE-1 to Colwellia maris sp. nov., a new psychrophilic bacterium. Int J Syst Bacteriol 48, 1357-1362. 